\title{
The influence of Fe-Mn oxides on the diffusion flux of $P$ at sediment-water interface
}

\author{
CAIXIANG ZHANG, YA XU AND ZENG FAN \\ China University of Geosciences (Wuhan) \\ Presenting Author: caixiangzhang@yahoo.com
}

Phosphorus (P) is a key influencing factor in the process of eutrophication, and its release at sediment-water interface can be regarded as an endogenous source of serious secondary pollution of surface water. In this paper, the concentration gradient between surface water (SW) and interstitial water (IW) as well as the sediment activity of $\mathrm{P}$ at sediment-water interface and the diffusion flux of $\mathrm{P}$ was also calculated according to diffusion flux method. In addition, the influences of Fe-Mn oxides on the diffusion flux of $\mathrm{P}$ were investigated. The results showed that the content of total phosphorus (TP) in interstitial water (with an average value of $0.445 \mathrm{mg} / \mathrm{L}$ ) was about twice as that in surface water $(0.22 \mathrm{mg} / \mathrm{L})$, total dissolved phosphorus (DTP) dominated both in interstitial water and in surface water,accounting for $78.8 \%$ and $53.6 \%$, respectively. Total phosphorus (TP) content in sediments are ranged from $0.31 \mathrm{mg} / \mathrm{g}$ to $1.3 \mathrm{mg} / \mathrm{g}$, with an average of $0.66 \mathrm{mg} / \mathrm{g}$. Especially, the content of exchangeable phosphorus (Fe-Al-P and OP) in sediments was can be regarded as the "source" of phosphorus, which has greater potential to release to overlying water. The mean diffusion flux of phosphorus is $0.028 \mathrm{mg} \cdot\left(\mathrm{m}^{2} \cdot \mathrm{d}\right)^{-1} \cdot \mathrm{T}$ he general trend of phosphorus diffusion direction at the sediment-water interface in this rainy season is from sediment to surface water. The diffusion flux of $\mathrm{P}$ is mainly influenced by environment factors (such as $\mathrm{pH}, \mathrm{DO}, \mathrm{TOC}), \mathrm{TP}$ concentration and $\mathrm{P}$ morphology, especially Fe-Mn oxides mediated by redox environment. The $\mathrm{P}$ diffusive flux at the sediment-water interface is sensitive to the overlying water quality, which can determine sediment transformation between P "source" and "sink". Endogenetic pollutant control should focus on endogenous governance and exogenous control.

This study was supported by the National Natural Science Foundation of China (Grant No. 41772251 and 42077184) 